\section{Upcoming Workshops}

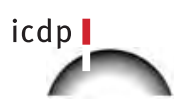

ICDP Workshop Potrok Aike

Lake Sediment Archive

Drilling Project (PASADO)

16-19 March 2006, Río Gal-

legos, southern Patagonia (Argentina)

More information at http://www.salsa.unibremen.de

An international research group is planning the research initiative "Potrok Aike Lake Sediment Archive Drilling Project" (PASADO) within the framework of ICDP. The intended project will address several key issues related to the evolution of maar craters, quantitative climatic and environmental reconstruction, fire history, tephra and dust deposition and palaeosecular variation of the Earth's magnetic field for the last several glacial to interglacial cycles. Moreover, dust and tephra records will provide links to marine sediment archives and ice cores. Obtained reconstructions of climate variability will be compared to climate simulations from global circulation models (GCM) to detect signals of climatic forcing.

\section{icdp I ICDP Workshop Scientific Drilling of the Snake River}

18-21 May 2006, Twin Falls, Idaho, U.S.A.

More information at http://www.usu.edu/ geo/hotspot/
The Snake River Plain represents a worldclass example of active mantle plume volcanism in an intra-continental setting. Because it is young and tectonically undisturbed, the complete record of volcanic activity can be sampled only by drilling. The preliminary scientific plan is to core a series of 4-6 drill holes along the axis of the eastern and western Snake River Plain in order to study the geochemical and stratigraphic variations in plume-related volcanism in space and time.

Interested parties should submit the application form available from the Web site to John Shervais at shervais@cc.usu.edu.

\section{icdp ICDP Workshop Lake Van Drilling Project - PaleoVan 6-9 June 2006, Van, Turkey}

More information at http://www.paleontology.uni-bonn.de/

Lake Van in Turkey is an excellent paleoclimatic archive comprising long high-resolution annually laminated sediment records covering several glacial-interglacial cycles. The lake is situated on the high plateau of eastern Anatolia. It is the fourth largest of all terminal lakes in the world and contains highly alkaline water.

Specific goals of the proposed PaleoVan project are to reconstruct the following: (1) Paleoclimate development in a sensitive semiarid region based on transfer functions (pollen, stable isotopes) and modeling; (2) Climatic variability in space and time based on teleconnection with other high-resolution records such as ice cores and marine sequences; (3) Dynamics of lake level fluctuations and hydrogeological development; (4) Formation and age of Lake Van; (5) History of volcanism and volcanic activities based on tephrostratigraphy; (6) Variations of the geomagnetic field; (7) Tectonic, paleoseismic and earthquake activities; (8) Interactions between man and environment since prehistoric time. Registration: All participants are requested to register through the registration form from the Web site to Thomas Litt (t.litt@uni-bonn. de). The registration deadline is 31 March.

\section{InterMARGINS \\ InterMargins Workshop on Climate-Tectonic Drilling in Southeast Asia}

5-7 June 2006, Kochi, Japan

More information at http://www.abdn.ac. uk/\%7ewpg008/RedRiverWorkshop.html

Interactions between the solid earth and the global climate system are a frontier area for ocean and Earth science research and have been highlighted as a focus area for the IODP. Of all the possible links between these earth systems, the proposed associations 
between the elevation of the Tibetan Plateau and the strength of the Asian monsoon are some of the most dramatic and controversial.

The workshop will explore the potential of using the Red River system as a means to understanding climate-tectonic interactions in Cenozoic Asia. The Red River is situated on the southeastern part of the Tibetan Plateau and is believed to have once been a much larger system that was reduced through time as drainage capture transferred the original headwaters to other major rivers in Asia. Since then, its drainage system has been influenced by the Asian Monsoon that is considered to be linked to Tibetan surface uplift. If these capture events can be dated, then these can be used to constrain the elusive uplift of Tibet.

For more information about the workshop, visit the Web site and contact the conveners.

Four IODP Workshops Announced for Summer/Fall 2006

More information on all IODP workshops can be found at http://www.iodp.org/workshops/

IODP-ICDP Workshop on IODP Fault Zone Drilling: Developing a Global Perspective icdp I 23-26 May 2006, Miyazaki, Japan

Application deadline: 21 February 2006

The IODP and the ICDP announce a joint Workshop on Fault Zone Drilling to address the science and technology of drilling, sampling, testing and long-term borehole monitoring of active faults. The objective of this workshop is to bring together the active team members of all fault-zone drilling projects for an open and detailed exchange of results, ideas, and experiences, fostering cooperation and synergy in the interpretation of findings, experiment design and technology development. Participants will be invited by the steering committee, with preference given to applicants from IODP and ICDP member countries. Some invitations will be reserved for advanced level students and early career scientists.

\section{- IODP IODP Workshop on Conti- nental Breakup and Sedi- mentary Basin Formation}

Tentative time and location: August-September 2006, Europe

Goals of this workshop are to formulate the key questions regarding the processes of continental rifting through the initiation of normal seafloor spreading; to compile a summary of the potential role for ocean drilling in addressing each key problem; and to come up with a global list of likely areas to be considered for drilling by IODP in the next decade to address these key problems. The studies should include assessments of what data exist and what data would be needed to make con- sideration for IODP drilling viable, as well as how and when these data might be acquired. The workshop should also address the following concerns: what combination of IODP drilling platforms (non-riser vessel, riser vessel operating with riser, riser vessel operating without riser, or special purpose platforms) are likely to be needed, and what general drilling strategies should be employed to address key problems.

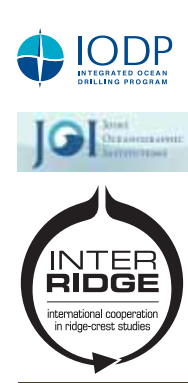

Mission to the MOHO-Formation and Evolution of Oceanic Lithosphere

Tentative time and location: $6-$ 9 or 10-13 September 2006, Portland, Oregon, U.S.A.

The goal of drilling a complete section through the oceanic crust and into the upper mantle has been reiterated Ridge 2000 throughout the history of ocean drilling and is embedded in the IODP Initial Science Plan as the "21st Century Mohole" initiative. Inherent in this goal is the tripartite need for a clearly defined scientific strategy, for parallel development of essential operational experience, and for phased development of the essential improved technologies, all of which are essential for the initiative to be fully realized.

This workshop will outline the scientific framework for a Mission to the Moho that will guide IODP's 21st Century Mohole initiative for a decade or more. The emphasis of the workshop is on the "Road to the Moho"-the scientific and engineering objectives and activities, beginning immediately and with available technology, that will lead us to the ultimate goal of a single deep "Mohole".

Please refer to the IODP web site for the latest information on how to register and attend.

\section{IODP/JOI Workshop on Exploring the Deep Bio- sphere with the IODP Tentative time and location: late September / early October 2006, Vancouver, Canada}

IODP considers the deep biosphere as a special focus area of the program. To encourage research and to stimulate the generation of drilling proposals, a workshop on this subject will be organized in collaboration with the Joint Oceanographic Institutions (JOI). If interested, please monitor the IODP Web site for further announcements and registration procedures on this workshop.

\section{icdp I \\ ICDP Workshop on the Magma-Hydrothermal Con- nection at Mutnovski Vol- cano}

September 2006, Petropavlovsk-Kamchatsky, Russia

More information at http://kamchatka.icdponline.org

Mutnovski volcano in Kamchatka, Russia and related nearby $700^{\circ} \mathrm{C}$ hot fumaroles provide an ideal geometry for exploring the magma-hydrothermal connection by drilling. A 62-MWe power plant taps a productive hydrothermal zone that strikes towards the vent of the Mutnovski volcano, $8 \mathrm{~km}$ away. Geochemical data support the view that the hydrothermal fluids are derived from the environment of Mutnovski's hot conduit. The workshop will include participants from a variety of disciplines, who will develop the rationale and scientific basis for a formal drilling proposal, site selection criteria, formation of a science team and outline of a proposal for submission to the ICDP and national funding agencies.

Interested researchers are invited to submit a brief summary of their field of research, describing their intended contribution to John Eichelberger at eich@gi.alaska.edu.

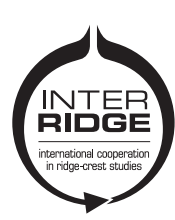
InterRidge Polar Ridges Meeting and Workshop 20-22 September 2006, Sestri Levante, Italy

More information at http:// www.interridge.org/SCIENCE/IRmeetings/2006PolarRidges.html

The mid-ocean ridges in the polar regions have become increasingly interesting as targets for scientific research during the recent years because of their key role in the formation of mid-ocean ridge basaltic melts, the breakup of continents, the evolution of life on Earth, ocean circulation and climate. To promote these initiatives, InterRidge has organized a workshop to exchange recent results of polar ridge research across disciplines, to formulate first-order questions and to produce a blueprint for the future of Arctic Ridge research. The workshop should also identify the resources and technology needed to conduct the exploration, and may lead to the formation of interdisciplinary projects.

The pre-registration deadline is $1 \mathrm{March}$ 2006. Please visit the InterRidge workshop Web site for the latest information. 